\section{Gordon L.M. Williams}

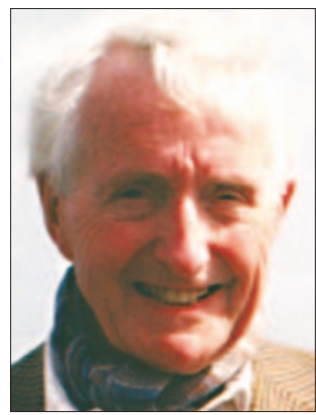

Gordon Williams died on 31 May 2004, just one month after his 89th birthday. He was born in Kingston upon Thames in 1915 and was educated at Tiffin's School, excelling academically and on both the rugger field and the river as an oarsman. In 1937 he qualified from Guy's Hospital Dental School, following his grandfather and father into the dental profession. After a six month house appointment at Guy's, he entered the family practice in Kingston which his mother had kept running with locums since his father's premature death.

By this time the war clouds were gathering fast and in 1938 Gordon was accepted for service in the Royal Navy; in 1941 he was commissioned as a Surgeon Lieutenant (D) RNVR and served for two years with the Fleet Air Arm at HMS Daedelus at Lee-on-Solent. Then, equipped with a student's dental cabinet and a foot engine, together with two ratings and transported in a $15 \mathrm{cwt}$ truck, he formed a mobile dental unit to treat service personnel based in the western desert ports of Mersa Matruh, Tobruk and Benghazi. After working under most primitive conditions, he was appointed to HMS Martial in Beirut and remained until the war ended. It was here that he met Patricia Crosbie, a Wren, to whom he was later married at a ceremony by the bishop in the Anglican cathedral in Jerusalem, his life long friend Ron Emslie acting as best man.

Gordon returned with his bride to Kingston where he resumed his single-handed practice for the next 36 years. During his service at Lee-on-Solent, Gordon became acutely aware that much of dental practice was little more than a repair service and determined to seek ways of preventing rather than treating caries and periodontal disease. This preventive philosophy dominated the remainder of his professional life, his practice in Kingston being one of the first in the country to be run on preventive lines.

Gordon served his profession in many ways. He was always keen to share his enthusiasm for prevention with colleagues and did so

\section{Gordon was a man of the highest integrity in all he undertook and as a member of our profession was an example to us all.}

with great effect as a member of the Guy's team, led by Professor Emslie, which during the 1960s and 70s put on lectures and seminars in preventive dentistry for GDPs in the southern counties.

Active in the BDA southern counties branch, Gordon held numerous positions, including president and life vice president. He served for 19 years on the BDA representative board and was vice chairman from 1980-1983 and was also a co-opted member of the dental health committee - elected vice chairman and subsequently chairman for two three-year periods. During his chairmanship he led a working party that produced a very popular and widely used series of dental health pamphlets. His sterling work for the association was acknowledged by his election as a fellow in 1982.

His other contributions included active membership of the British Society of Periodontology, the Fluoridation Society, the British Association for the Study of Community Dentistry, the Surrey LDC and the Kingston and Richmond LDC. He published a number of papers on preventive and community dentistry in the $B D J$.

Gordon was a much loved and highly respected man whose enthusiasm for everything he undertook was greatly appreciated and admired by his colleagues and his patients. He was a man of the highest integrity in all he undertook and as a member of our profession was an example to us all.

Outside his professional life, Gordon was devoted to his family and home with special interest in his garden. He derived great pleasure driving his Rover cars, travelling, reading poetry and listening to music.

Gordon's many friends and colleagues will wish to extend to his wife Patricia, and their surviving children John, Penny and Sally their deep-felt sympathy.

M.N. Naylor 